\title{
THE USE OF WALL CHARTS AS MEDIA TO TEACH VOCABULARY
}

\author{
Lilis Patria, Sudarsono, Eni Rosnija \\ Universitas Tanjungpura, Pontianak \\ lilisp58@gmail.com,sudarsono@fkip.untan.ac.id,enirosnija@yahoo.com
}

Submitted: 2020-09-02

Accepted: 2020-11-18

\begin{abstract}
This research was designed to improve the students' vocabulary using wall charts as a learning medium. It is a classroom action research with two cycles. The procedures of each cycle were planning, acting, observing, and reflecting. The research subjects numbered 31 students of Learning Group VII, SMP Negeri 2 Belitang Hilir. The data were collected quantitatively and qualitatively, namely classroom observation, interviews, test scores, and questionnaires. The research findings showed that the students could improve to memorize the vocabulary and its meaning with the help of wall charts. The teacher could also help them correct spelling and pronunciation. Moreover, the students' attitude towards the teaching-learning process improved since the wall charts increased the students' interest in learning English vocabulary. It can be seen that in Cycle 1 was 67 and in Cycle 2 was 81.9. The research result also showed that the wall chart was a good medium for learning English vocabulary with a mean value of 4.52.
\end{abstract}

Keywords: Wall Charts, Vocabulary, Junior High School Students

\section{INTRODUCTION}

Teaching English to teenagers get more attention from society. It is essential to introduce a foreign language, especially English, to teenagers. To be skilled well in a language, the students need to master its grammar and vocabulary. These two areas of language acquisition must go hand in hand in the teaching-learning process. One can communicate with a little grammar, but it is almost impossible to communicate without a sufficient amount of vocabulary (Utami, 2014). The teaching of vocabulary is not easy because English has huge numbers of words (Rohmatillah, 2012). Teaching vocabulary is one of the least efficient ways to develop students' language knowledge (Thornbury, 2002). The English teachers teach their junior high school students basic English vocabulary. This type of vocabulary generally covers the simple English words that the students encounter in their daily life, such as days, months, people, animals, and things (Nasution, 2008).

A wall chart is a large card displaying a diagram or picture used by the teachers to improve the English vocabulary mastery of their students. Wall charts commonly consist of a combination of visual and verbal materials. Kang (2015) refers a chart to a large sheet of paper or card with a text, picture, or diagram that the teachers can hold up for the class to see or display on the wall or blackboard used for extended presentation or practice. Wall charts may also be defined as the collections of pictures, diagrams, or graphs on large sheets of strong paper (Duminy, 1992) that are used for the structure practice and drill, as well as a dialogue elaboration (in a social situation) and discussion (Bowen, 1994). 
In reference to the preliminary observation, there were problems encountered in the teaching process. The classroom was not completed with a projector. The teacher used a blackboard, the only teaching tool available in the classroom, to write the new words that the students did not know encountered in the teaching materials and the working sheets. In addition, the teacher did not apply various teaching techniques to teach the students and did not prepare teaching-learning media. The teacher just asked the students to find their meaning to list on a piece of paper. Thus, the lack of teaching-learning facilities and teaching-media, as well as the monotonous teaching techniques applied by the teacher in class might result in the students' poor mastery of vocabulary.

One of the solutions to the students' poor vocabulary mastery was that the teacher needed to prepare the appropriate teaching media, namely, wall charts. This medium was introduced to replace the projector to teach vocabulary. It was necessary to improve the students' poor mastery of vocabulary. Wall charts were required to enable the students to memorize English vocabulary better. This medium was also functional to help the students understand the meaning of English words that they learned.

Some studies have proven that wall charts could improve students' vocabulary mastery. Maharani (2012) reported that wall charts improved the students' motivation in learning vocabulary in an elementary school. Through the wall charts, the students got interested and enthusiastic to listen to the teacher's explanation, to pay more attention to the lesson, to participate in class well during the teaching and learning process.

Using wall charts was reported by Azizah (2016) that it was beneficial to improve the students' writing skills. Through this medium, the students could memorize and understand the new vocabulary faster. Another study, which was administered by Evetsson (2014) reported that the wall charts that were applied in a Swedish elementary school could increase the students' achievement.

Thus, it was significant to conduct a study about the use of wall charts to improve the students' vocabulary mastery in SMP Negeri 2 Belitang Hilir. The subjects of the research were Learning Group B of Year-7 students. It was a classroom action research.

\section{METHOD}

The present study was classroom action research (CAR). This type of research integrates research, action, and analysis (O'Byrne, 2016) that will help the teachers discover what works best in their classroom situations (Mettetal, 2015). Classroom action research (Burns, 2010) is implemented in cycles. Each cycle involves four steps. They are planning, acting, observing, and reflecting as shown in Figure 1. 
Figure 1: Steps of an Action Research Designed by Burns (2010)

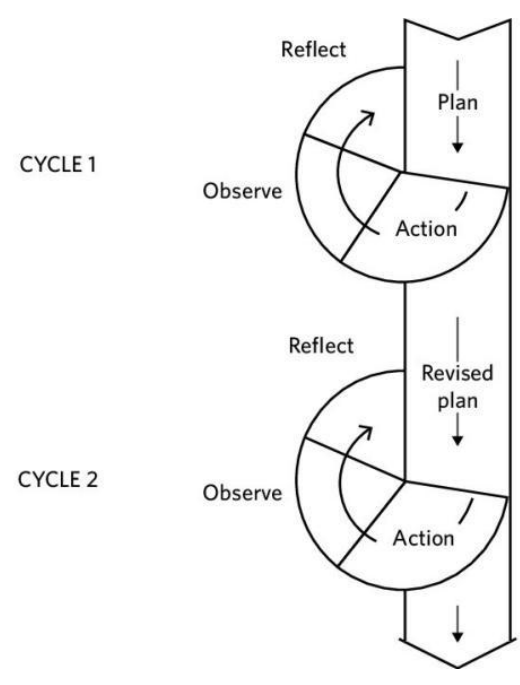

Referring to the above figure, the first stage involved teaching and learning planning. This step included the problems and situation analysis identified in the previous teaching and learning process and the preparation of the instruments to collect the data. The researcher, together with the teacher, planned the implementation of wall charts to teach vocabulary in the relevant class. Then, the teaching and learning procedure, scenario, guidelines, and instruments to collect the data were prepared.

The second step was acting. In this stage, the teacher implemented the teaching and learning activities as planned in the first step, that is, the teacher used wall charts in teaching vocabulary to the students. In the first cycle, the teacher explained the material to the students. Then, they were assigned in groups to stick the appropriate pictures of professions and to describe them. After that, their products were presented in front of their class.

The third stage was observing. In this stage, the research data were collected with various tools. The tools to observe included a checklist, field note, and written.

The last step was reflecting in which the teacher recalled all the materials delivered in class. All of the data collected were analyzed and discussed by the researcher and the co-researcher to find out whether the students got an improvement in each cycle. The result of reflection would be used to have the planning for the next cycle if it was still required.

The subjects of the present research were the Learning-Group-B students of Year-7, SMP Negeri 2 Belitang Hilir. This learning group consisted of 31 students. They had poor mastery of vocabulary. 
The data were collected through observation covering checklists, field notes, tests, questionnaires, and interviews. The checklist was applied to observe what happened during the teaching and learning process, both the strengths and weaknesses of implementing wall charts in class. The field note was used to take notes of anything that has happened in the classroom and the students' behaviors during the lessons that did not involve in the observation checklist. The test was implemented before and after the teaching-learning process to see the level of improvement. The questionnaires were applied to collect the data about the information, namely, the students' perception towards wall charts as media for learning vocabulary. The interview is administered to know the teacher's opinion about the implementation of wall charts and how the influence of wall charts on their teaching and learning process.

All of the collected data were analyzed using a qualitative and quantitative approach. The last step was having a conclusion made a conclusion based on the observation result qualitatively. The quantitative data collected from were analyzed to calculate the mean value, and verbal interpretation than can be seen below.

The final score for each student for every test is counting using the following formula:

Students' score $=\frac{\text { Correct Answer }}{\text { Total of Question }} \times 100$

The students' scores were computed to have the mean score. The formula is applied (Sugiono, 2015).

$$
\mathrm{M}=\frac{\sum x}{n}
$$

Legends :

$\mathrm{M}=$ Mean score

$\sum \mathrm{x}=$ The sum of the students' score

$\mathrm{n}=$ Total number of the student

The obtained score was classified as shown in the following table.

Table 1. The Classification of Students' Mean Score

\begin{tabular}{|l|l|}
\hline \multicolumn{1}{|c|}{ TOTAL SCORE } & QUALIFICATION \\
\hline $80-100$ & Good to excellent \\
\hline $69-79$ & Average to good \\
\hline $50-64$ & Poor to good \\
\hline $0-49$ & Poor \\
\hline
\end{tabular}


To compute the mean, the following formula (Bringula, 2012) was applied.

$$
X=\sum \frac{w x}{N}
$$

Legends:

$\mathrm{X}$ : weighted mean

W: weighted factor

$\sum$ : sum of

$\mathrm{N}$ : total number of students

$\mathrm{x}$ : score

Then, the obtained mean score was categorized into the following criteria.

Table 2. Data Interpretation Criteria

\begin{tabular}{|l|l|l|}
\hline \multicolumn{1}{|c|}{ Rate } & Verbal interpretation & \multicolumn{1}{c|}{ Range } \\
\hline 5 & Strongly agree & $4.51-5.00$ \\
\hline 4 & Agree & $3.51-4.50$ \\
\hline 3 & Neutral & $2.51-3.50$ \\
\hline 2 & Disagree & $1.51-2.50$ \\
\hline 1 & Strongly disagree & $1.00-1.50$ \\
\hline
\end{tabular}

\section{FINDING AND DISCUSSION}

The research was conducted in two cycles. This research found out that using wall charts could improve the students' vocabulary mastery. The use of this media also made the students more active, enthusiastic, and attentive to the teacher's explanation.

\section{First Cycle}

It was noted that in this cycle the students did not pay attention to the teacher's explanation; the class was noisy. Some students answered questions and the others shouted at them. To make them quiet, the teacher asked the students to be quiet, by not continuing the explanation until the students kept silent. 
After they were ready to study, the teacher continued delivering the lesson while writing the new words on the blackboard. Most of the students were not familiar with the vocabulary of professions. The finding showed that the students' behaviors were so poor and the average score of their vocabulary mastery was so 'moderate', 67,8 , that the teacher and the researcher concluded to run the second cycle.

The students needed to improve their behaviors on readiness to start the learning, to study in smaller groups, and to manage the learning time.

\section{Second Cycle}

In this cycle, a new step and activity were added to the teaching and learning process to improve students' behavior in class. From the beginning of the class, the students showed their readiness to study vocabulary. Group works were also implemented in the second cycle. They brought positive changes to the students' involvement and collaboration in their learning process. They were enthusiastic to share information and to work together in smaller groups to solve problems. The result was that the students were not afraid of answering questions in English any longer.

Besides, the students improved in mastering vocabulary as shown in the test result. Their average score was 8,91, excellent. This score reached the passing grade defined by the school. Most students perceived very positively that using wall charts helped them memorize the vocabulary faster. Wall charts could draw students' attention and made them participated actively in class. The students became very active during the teaching and learning process, the group works and the time allocation was managed better in this cycle.

In this classroom action research, the researcher decided to use wall charts as media to improve students' vocabulary mastery. In the first cycle, the teacher started the teaching and learning process by showing wall charts to stimulate the students. Then, the students shared their ideas in a group discussion session and presented their opinions about their topic in front of the class. In the second cycle, the researcher attempted to gain the students' comprehension by re-explaining the guidelines. Then the teacher recalls the vocabulary that has been mention by the students in the group discussion session to help the students memorize the vocabulary faster.

Through the cycles, the students acquired a better command of vocabulary. They could respond to the instruction well without asking the teacher for translation. They tried their best to explain the meaning of words by using English even though they still forgot some words. 
Quantitative, the students' improvement in mastering vocabulary can be shown from the mean score in Cycle 1 to mean score in Cycle. The quantitative improvement can be seen in the following graph.

\section{Graph 1: The score comparison between cycle 1 and cycle 2}

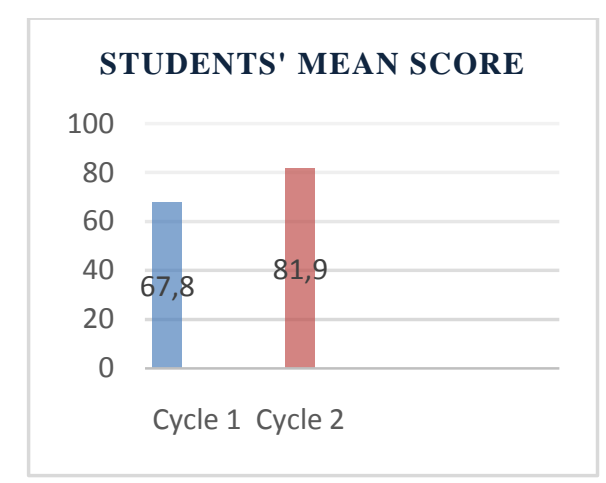

In the first cycle, there were only 15 students, but in the second cycle, there were 29 students who passed the KKM (70).

On the other hand, the data of the questionnaire also showed that the students perceived learning vocabulary positively. Most of them responded "totally agree", scoring 4,52 that the wall charts were very functional media to improve the students' vocabulary mastery. They also perceived that by using wall charts they could improve in memorizing the vocabulary.

In reference to the findings in Cycle 1 and Cycle 2, the students improved their learning behaviors. Their behavioral improvement was satisfying. Positive learning behavior is derived from the positive attitudes towards teaching and learning activities. Aristo, Sudarsono, \& Sada (2019) claim that positive behaviors may stimulate the learning process, or may result in successful learning achievement as proven in the finding of the present research. The students succeeded in improving the vocabulary mastery both in the forms and the meaning.

Another finding of this research was that the students participated actively in the classroom. The active learning participation may be produced by "the behavioral dimension of engagement" that can be identified by "the attendance to the class, involvement the classroom activity vividly, and absence of disruptive or negative behavior" (Ikhsanuddin, Sudarsono, \& Salam, 2019).

The group members not only participated in the class in using the wall charts but also in making the wall charts to help them memorize the words. Learning in pairs or groups makes the students learn in a comfortable feeling and enable them to get confident (Aristo, Sudarsono, \& Sada, 2019). Emotionally, the students can be implicitly identified as showing "affective reactions of interest, enjoyment, and sense of belonging" and 


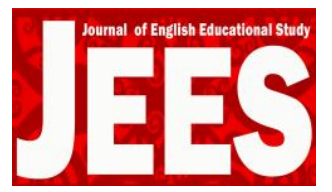

Journal of English Educational Study

Volume 3 Issue 2 November 2020 Page 169-177

E-ISSN: 2655-0776

cognitively the students have attempted to learn "beyond the requirement or to relish challenge" (Ikhsanuddin, Sudarsono, \& Salam, 2019).

\section{CONCLUSION}

In reference to the research findings, the use of wall charts as media is beneficial to improve students' vocabulary mastery. It helped students memorize and understand the vocabulary faster. The research finding also showed that the students were able to find the meanings, spelling the words, and use of words. Therefore, the students were capable of using more vocabulary in describing the pictures using wall charts as learning media.

The data from each cycle that were collected during the research showed that the students' vocabulary mastery improved. Wall charts were functional to make the students more active in teaching and learning activities. The students initially with poor attention to the teacher's explanation progressively improved their attention to the teacher. Because of their behavioral improvement, the students improved their learning participation which then they got better mastery as indicated by the mean score in each cycle.

\section{REFERENCES}

Aristo, Sudarsono, \& Sada, C. (2019). Circle Talk in Natural Approach to Improve Students'. IJLI (International Journal of Learning and Instruction), Vol. 1/1, 1-11.

Azizah, S. M. (2016). The use of wall charts to improve students' vocabulary mastery. Unpublished undergraduate thesis. Yogyakarta: Yogyakarta State University.

Bowen, T. (1994). The teacher development series: Inside Teaching. New Hampshire: Heinemann.

Bringula, R. (2012). School choice of computing students: A comparative perspective from two universities. . Creative education. Vol. 3, 1070-1078.

Burns, A. (2010). Doing Action Research in English Language Teaching. New York: Routledge.

Duminy, P. A. (1992). Teaching Practice. Cape Town: Maskew Miller Longman.

Evetsson, J. (2014). Classroom wall charts and biblical history: a study of educational technology in elementary school. International Journal of the History of Education. Vol. 50 Issue 5, 668-684.

Ikhsanuddin, Sudarsono, \& Salam, U. (2019). Using magic trick problem-based activities to improve engagement in a listening class. JELTIM (Journal of English Language Teaching Innovations and Materials) Vol 1/1, 7-15.

Kang, N. J. (2015). English learning areas in pre-primary classrooms: An Investigation of their effectiveness. London: British Council.

Maharani, S. S., \& Pudjobroto, A. H. (2012). Improving students' vocabulary mastery through the use of wall charts in elementary students. 2, 1-18.

Mettetal, G. (2015). Improving teaching through classroom action research. Research Gate, 14.

Mettetal, G. (2015). Improving teaching through classroom action research. ResearchGate, 14.

Nasution, K. (2008). Learning to read words. The Quarterly Journal of Experimental Psychology, 61 (8), 1121-1133.

O'Byrne, W. I. (2016). Four steps to conducting action research in the classroom. Ian O'Byrne.

Rohmatillah. (2012). A study on students' difficulties in learning vocabulary. Jurnal Pendidikan.

Sugiono. (2015). Statistik itu mudah. Kotagede: Ladang Kata.

Thornbury, S. (2002). How to teach vocabulary. London: Pearson Education Limited. 
Journal of English Educational Study

Volume 3 Issue 2 November 2020 Page 169-177

E-ISSN: 2655-0776

Utami, Y. S. (2014). Improving students' vocabulary mastery using crossword puzzles for grade VII of SMP Negeri Srandakan in Academic Year 2013/2014. Yogyakarta: Universitas Negeri Yogyakarta. 